\title{
Potential loss of nutrients from different rearing strategies for fattening pigs on pasture
}

\author{
J. Eriksen ${ }^{1}$, J. E. Hermansen ${ }^{1}$, K. Strudiholm ${ }^{1} \&$ K. Kristensen ${ }^{2}$ \\ Departments of ${ }^{1}$ Agroecology, and ${ }^{2}$ Genetics and Biotechnology, Danish Institute of Agricultural Sciences, PO Box 50, 8830 Tjele, \\ Denmark
}

\begin{abstract}
Nutrient load and distribution on pasture were investigated with fattening pigs that: (1) spent a proportion of or their entire life on pasture; (2) were fed either restrictively or ad libitum; and (3) were weaned at different times of the year. $\mathrm{N}$ and $\mathrm{P}$ retention in pigs decreased the longer they were kept on pasture. The contents of soil inorganic $\mathrm{N}$ and exchangeable $\mathrm{K}$ were significantly raised compared with the soil outside the enclosures but with no differences between treatments. Pig grazing did not affect extractable soil P. Regular moving of huts, feeding and water troughs was effective in ensuring that nutrients were more evenly distributed on the paddocks. Grass cover, as determined by spectral reflectance, was not related to the experimental treatments but only to the time of year. During spring and summer, grass was present in parts of the paddocks, whereas during autumn and winter, the pigs kept grass cover below $10 \%$. Fattening pigs on pasture carry a high risk of nutrient loss and it is concluded that the most environmentally acceptable way of keeping them on pasture involves a combination of reduced dietary $\mathrm{N}$ intake, reduced stocking rate and seasonal rather than round the year production.
\end{abstract}

Keywords: Outdoor pigs, nitrogen, potassium, phosphorus, grass cover, environmental impact

\section{Introduction}

Outdoor rearing of pigs is perceived by many consumers as being more natural and animal-friendly than conventional production systems. Thus, an increasing number of sows are being kept outdoors in Europe in large-scale, intensive outdoor systems (Watson et al., 2003). In Danish organic pig production, sows are typically kept outdoors all year round and young pigs are moved to an indoor pig unit with access to an outdoor run with a concrete floor when they are weaned at 7 weeks (Hermansen et al., 2004). It seems paradoxical that despite the fact that much meat derives from supposedly natural outdoor systems, the pigs spend the majority of their life in indoor systems prevented from carrying out natural behaviour such as rooting, digging and grazing. A possible explanation is the expected drawbacks of rearing fattening pigs outdoors including the huge space demand and high labour input, greater food consumption and environmental costs because of nutrient losses to water bodies and to

Correspondence: J. Eriksen. E-mail: jorgen.eriksen@agrsci.dk Received September 2005; accepted after revision March 2006 the atmosphere caused by the large nutrient load and difficulty in maintaining grass cover. However, it is doubtful that (even partial) indoor rearing of pigs can comply with the animal welfare standards that consumers expect from outdoor pig production systems, and consequently better systems need to be developed for fattening pigs on grassland.

The environmental impact of outdoor pig production is to a large extent related to the nutrient content in the supplementary feed for the pigs and the stocking density because it has proved difficult to obtain optimal utilization of the nutrients deposited during grazing (Zihlmann et al., 1997; Williams et al., 2000, 2005; Eriksen \& Kristensen, 2001). As a consequence, there are considerable losses from grazed pastures leading to an undesirably small nutrient availability in the rest of the crop rotation. Nitrogen losses from outdoor pigs in the form of nitrate leaching (Eriksen, 2001), ammonia volatilization (Sommer et al., 2001) and denitrification (Petersen et al., 2001) contribute to eutrophication of natural environments, acid rain and global warming, respectively (Wang et al., 1976; Ryden et al., 1984; Schulze et al., 1989). Lack of available nutrients later in the rotation, because of losses from outdoor pig fields, has adverse effects on the 
economic profit of the farmer because it causes decreasing crop yields or increased need for supplementary fertilizer import. To obtain sufficient feed production and to protect ground water and the atmosphere from pollution, it is necessary to improve the nutrient use efficiency (NUE) in pastures grazed by pigs. In previous investigations in sow paddocks (Eriksen et al., 2002) on the fate of $\mathrm{N}$ in outdoor pig feed, $44 \%$ of the $\mathrm{N}$ could be accounted for in piglets, $13 \%$ as ammonia volatilization, $8 \%$ as denitrification and $16-35 \%$ as nitrate leaching. In these investigations, nutrient distribution was of major importance for nutrient utilization. Without regularly changing the position of the shelters and feeders during grazing, the deposition of excreta by the sows became extremely uneven and caused substantial nitrogen losses, particularly around the feeding areas.

Little is known about the magnitude of the risk of nutrient losses from fattening pigs on pasture. Salomon et al. (2005) undertook comprehensive studies of the behaviour of fattening pigs on pasture and found the highest number of defecations and urinations between huts and the feeding troughs, indicating that these systems may suffer from an uneven distribution of nutrients. Similarly, Stern \& Andresen (2003) found that areas with huts, drinking points and wallows were used for excretion. However, they also found that newly allotted areas were used intensively for defecation and urination, and suggested this as a way to encourage a more even distribution of manure.

Nutrient balances are often used to evaluate if environmental targets have been meet. The advantages of balances are the quantitative nature and the value as a management tool, but they also have some serious shortcomings (Öborn et al., 2003). The main one is the inability to estimate internal flows, which is a major obstacle when applying nutrient balances to estimate potential losses, and the fact that they only address total amounts of nutrient and ignore availability (Öborn et al., 2003). Furthermore, the spatial nature of soil nutrient distribution observed in outdoor pig production has important consequences for the interpretation of nutrient balances (Watson et al., 2003). Without homogeneous nutrient distribution, decreasing stock densities or dietary inputs may not contribute to better nutrient efficiency. Thus it is important to supplement nutrient balances with an evaluation of nutrient distribution.

A Danish study has investigated the effects of different rearing strategies for outdoor fattening pigs on performance and carcass characteristics (Oksbjerg et al., 2005; Strudsholm \& Hermansen, 2005). Compared with pigs fed ad libitum indoors, outdoor pigs fed ad libitum did not differ in daily gain, but ate more feed. Restricted feeding outdoors reduced daily gain but improved feed conversion to a level similar to that for indoor feeding. Pigs reared outdoors until $80 \mathrm{~kg}$ of live weight, or permanently, had improved carcass characteristics with leaner meat and less back fat, and the restrictively fed outdoor pigs also had a higher proportion of polyunsaturated fatty acids in muscles. It was concluded that outdoor rearing may be a competitive option even all year round, in a temperate climate.

This paper reports an associated study focusing on the environmental impact of these strategies. The specific objectives were to evaluate NUE and nutrient load and distribution in outdoor pens with fattening pigs that: (1) spend a proportion of, or their entire, life on pasture: (2) are fed either restrictively or ad libitum; and (3) are weaned at different times of the year.

\section{Materials and methods}

\section{Experimental set-up and pig management}

The experiment was established at Rugballegaard Experimental Station, Denmark. The soil is a sandy loam with $8.5 \%$ clay and $2.3 \%$ carbon, classified as a Glossic Phaeozem according to the FAO system (Schjønning et al., 2002). The experiment was designed to investigate the performance from weaning to slaughtering of pigs fed and housed differently. Piglets born on grassland were consigned at weaning to five different treatments (Table 1) that were replicated five times during 1 year, starting in January, April, August, October and December. Each experimental unit consisted of 10 pigs that were allocated concentrates daily in a trough with simultaneous access for all pigs. For more details on pig breed, diet and feeding, see Strudsholm \& Hermansen (2005).

The grassland was a second year grass-clover pasture and each treatment in each replicate was introduced to a new piece of land. All paddocks were $10 \mathrm{~m}$ wide but differed in length and thus total area (Table 1). The stocking rate was calculated to cause a nitrogen deposition of $280 \mathrm{~kg} \mathrm{~N}^{-1}$ based on the national definition of a livestock unit and the national guidelines allowing pastures to be used for grazing pigs only every other year (European Commission, 2000; Ministry of Environment, 2002). This is the minimum space

Table 1 Treatments in experiment with fattening pigs on pasture

\begin{tabular}{llc}
\hline Treatments & \multicolumn{1}{c}{ Description } & $\begin{array}{l}\text { Paddock } \\
\text { area }\left(\mathrm{m}^{2}\right)\end{array}$ \\
\hline $\begin{array}{l}\text { 1. In } \\
\text { 2. In }(40 \mathrm{~kg})\end{array}$ & $\begin{array}{l}\text { Transferred indoors at weaning } \\
\text { Transferred indoors at } 40 \mathrm{~kg} \\
\text { live weight }\end{array}$ & $\begin{array}{l}\text { None } \\
205\end{array}$ \\
3. In (80 kg) & $\begin{array}{l}\text { Transferred indoors at } 80 \mathrm{~kg} \\
\text { live weight }\end{array}$ & 776 \\
4. Out (restrictively) & $\begin{array}{l}\text { Outdoors until slaughter }-\mathrm{fed} \\
\text { restrictively }\end{array}$ & 1108 \\
5. Out (ad libitum) & $\begin{array}{l}\text { Outdoors until slaughter }-\mathrm{fed} \\
\text { ad libitum }\end{array}$ & 1108 \\
\hline
\end{tabular}

There were 10 pigs in each treatment. 


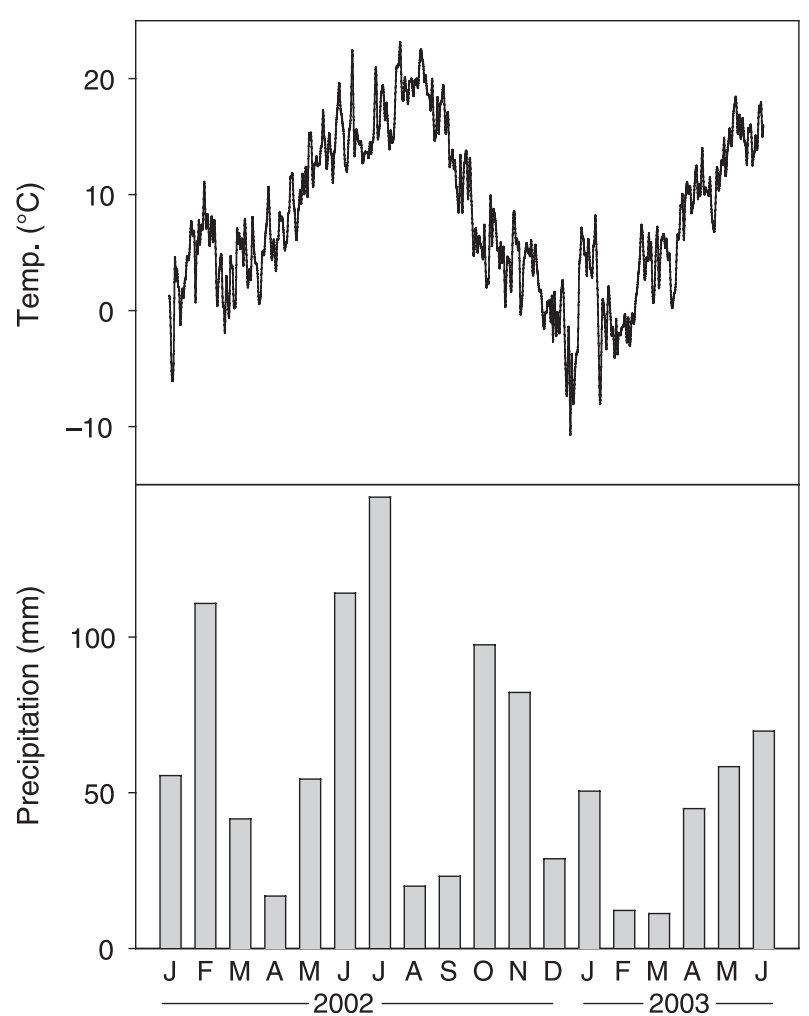

Figure 1 Temperature and precipitation during the experimental period.

required for outdoor pigs within the current regulations on nutrient load. The huts, feeding and water troughs were moved every 4 weeks to minimize hot spots caused by animal excretions or feed waste.

The climatic conditions are illustrated in Figure 1. Precipitation during the experimental period was $1037 \mathrm{~mm}$, which is slightly lower than the 30-year mean (1960-1991) of $1199 \mathrm{~mm}$.

\section{Soil sampling and analyses}

Soil samples were collected on a $5 \mathrm{~m} \times 5 \mathrm{~m}$ grid each time pigs were transferred from the field to housing or slaughter and reference samples were taken at $5 \mathrm{~m}$ intervals outside the paddocks. Eight soil samples were taken at $0-40 \mathrm{~cm}$ depth on a $20-\mathrm{cm}$ radius circle around each point and bulked. The samples were stored frozen until they were processed. The contents of ammonium and nitrate were determined spectrophotometrically on all the bulked samples after extraction with $1 \mathrm{~m} \mathrm{KCl}(1: 2 \mathrm{w} / \mathrm{v})$. The extractable phosphate (Olsen et al., 1954) and exchangeable potassium (Thomas, 1982) was determined on dried soil.

\section{Determination of grass cover}

Grass cover was estimated by determining the spectral reflectance of the paddocks. The hand-held equipment con- sists of two sensor units, one unit measuring the red $(650 \pm 10 \mathrm{~nm})$ and the near-infrared $(800 \pm 10 \mathrm{~nm})$ reflection from the canopy and another similar unit the incoming radiation. The sensor units of type SKR 1800 with a $15^{\circ}$ view were connected to an analogue-to-digital (A/D) converter of type SDL2500 (Skye Instruments Ltd, UK) and data were recorded on a computer. All observations were taken at a height of $1.8 \mathrm{~m}$, representing $0.5 \mathrm{~m}^{2}$ ground area. The spectral reflectance measurements were converted to a mean value of the relative vegetation index (RVI). At each point of soil sampling, a simultaneous determination of RVI was made. At each sampling date, RVI was determined for bare soil and for $100 \%$ grass cover as a reference and the grass cover at each point was determined from interpolation between these values.

\section{Nutrient balances}

Nutrient balances for $\mathrm{N}$ and $\mathrm{P}$ were calculated as nutrient input in feed and pigs minus the nutrient output in pigs (live weight gain). All feeds and pigs entering and leaving the individual paddocks were weighed. The nutrient content of feeds and pigs was estimated based on the feed manufacturer's production report on the feed mixtures and on the literature values regarding pigs and other feedstuffs. These were as follows (g N and $\mathrm{g} \mathrm{P}$ per $\mathrm{kg}$, respectively): feed mixture at weaning (32.2 and 6.6), feed mixture at fattening (30.7 and 5.5), crushed oats [12.0 and 3.6, (Pedersen, 2000)], grass-clover silage [8.7 and 1.3, (Møller et al., 2000)], straw for bedding [5.4 and 0.7, (Møller et al., 2000)], piglets [27 and 5.5, (Poulsen \& Kristensen, 1997)] and finishers [28 and 5.5, (Poulsen \& Kristensen, 1997)]. The nutrient balance is the net surplus at paddock level and does not include losses after excretion (ammonia, denitrification and nitrate leaching).

\section{Statistical analysis}

Nutrient balances. Analysis of variance was carried out using the general linear model (GLM) procedure of SAS (SAS Institute Inc., 1999) to estimate differences between treatments in $\mathrm{N}$ and $\mathrm{P}$ inputs, outputs, surplus and NUE.

Nutrient deposition and grass cover. Data was first reorganized to give an observation for each combination of treatment, replicate and position along the paddock so each observation inside the paddocks was the average of the two data points taken across the $10-\mathrm{m}$ wide paddocks with a corresponding outside observation. Of the total 948 soil samples retrieved during the experiment, four samples from outside the paddocks were ignored because of abnormal values that could be related to fodder spill. Each of the variables inorganic $\mathrm{N}$, extractable $\mathrm{P}$, exchangeable $\mathrm{K}$ and percentage grass cover was analysed using a general linear mixed model (see, 
e.g. Searle et al., 1992). The model included the fixed effect of replicate, treatment and the corresponding outside observation. The random effect of each paddock (combination of replicate and treatment) was assumed to have a constant variance, whereas the variance of the residual effects (within paddock) were approximated by a sum of two components one specific for each replicate and one specific for each treatment. More formally, the model may be written as:

$$
Y_{g b x}=\mu+\alpha_{g}+\beta_{b}+\gamma Z_{g b x}+D_{g b}+E_{g b x},
$$

where: $Y_{g b x}$ is the mean of two observations in the paddock of treatment $b(2-5)$ at position $x$ in replicate $g(1-5) ; Z_{g b x}$ the value outside the paddock of treatment $b$ at position $x$ in replicate $g ; \mu, \alpha_{g}, \beta_{b}$ and $\gamma$ the fixed effects of level, replicate, treatment and value ouside the paddock, respectively; $D_{g b}$ the random effect of the paddock on treatment $b$ in replicate $g$; $E_{g b x}$ the residual effect of the paddock on treatment $b$ at position $x$ in replicate $g . D_{g b}$ is assumed to be normally distributed with mean zero and variance $\sigma_{D}^{2}$ and $E_{g b x}$ is assumed to be normally distributed with mean zero and variance $\sigma_{g b}^{2}$ with $\sigma_{g b}^{2}=\theta_{g}+\tau_{b}$, where $\theta_{g}$ and $\tau_{b}$ are the additive variance components for replicate and treatment, respectively. In order to obtain unique estimates of $\theta_{g}$ and $\tau_{b}$, we let $\tau_{5}=0$.

The parameters of the model were estimated using the procedure MIXED of SAS (SAS Institute Inc., 1999). Unless otherwise stated, differences mentioned in the text are significant at the $5 \%$ level.

\section{Results}

\section{Nutrient balance}

The aim of the design was to minimize the space requirement within the current regulations on nutrient load and at the same time use current knowledge on how to encourage uniform excretion behaviour by pigs through paddock design and management. The stocking rate was calculated to result in a $\mathrm{N}$ load in manure of $280 \mathrm{~kg} \mathrm{~N}^{-1}$ based on the national definition of a livestock unit and the national guidelines allowing pastures to be used for grazing pigs only every other year. However, the actual nitrogen surplus of the paddocks (Table 2) considerably exceeded the intended $280 \mathrm{~kg} \mathrm{~N} \mathrm{ha}^{-1}$. This was caused by a combination of a $20 \%$ higher $\mathrm{N}$ content of the organic feed and greater feed consumption (by in particular the ad libitum fed pigs) than the consumption by conventionally managed pigs that form the basis for the definition of animal units and nutrient load. The NUE in the paddocks (feed $\mathrm{N}$ input relative to animal $\mathrm{N}$ output) decreased the longer pigs were kept on pasture as a result of the well-documented increased feed consumption per $\mathrm{kg}$ gain and reduced $\mathrm{N}$ retention with increased live weight (Fernandez et al., 1999). Thus $\mathrm{N}$ in piglets kept outside until $40 \mathrm{~kg}$ accounted for $38 \%$ of feed $\mathrm{N}$ input, whereas $\mathrm{N}$ in piglets on pasture until slaughter accounted for only $30 \%$ of feed $\mathrm{N}$ input. These figures can be compared with typical figures for $\mathrm{N}$ retention in indoor conventional pig production system of $47 \%$ for weaners and $37 \%$ for growers (Fernandez et al., 1999).

As feed consumption had a pivotal influence on the nutrient input, the $\mathrm{P}$ surplus was proportional to the $\mathrm{N}$ surplus but the NUE was 3-4\% higher than for N and close to typical values for P-retention of 35\% (Fernandez et al., 1999). In the two replicates running from February to August, feed consumption was significantly lower than during autumn and winter, leading to a smaller nutrient surplus and higher NUE. Sather et al. (1997) observed less feed intake during summer for free-range growers $(14 \%)$ and a correspondingly improved feed conversion.

Table 2 Nutrient balance and nutrient use efficiency (NUE) for $\mathrm{N}$ and $\mathrm{P}$ in paddocks with fattening pigs on pasture

\begin{tabular}{|c|c|c|c|c|c|c|c|c|}
\hline & \multicolumn{4}{|c|}{$N\left(\mathrm{~kg} \mathrm{ha}^{-1}\right)$} & \multicolumn{4}{|c|}{$\mathrm{P}\left(\mathrm{kg} \mathrm{ha}^{-1}\right)$} \\
\hline & Input & Output & Surplus & NUE (\%) & Input & Output & Surplus & NUE $(\%)$ \\
\hline \multicolumn{9}{|l|}{ Treatments } \\
\hline In $(40 \mathrm{~kg})$ & $695^{\mathrm{a}}$ & $261^{\mathrm{a}}$ & $434^{\mathrm{b}}$ & $38^{\mathrm{a}}$ & $128^{\mathrm{a}}$ & $52^{\mathrm{a}}$ & $76^{\mathrm{ab}}$ & $41^{\mathrm{a}}$ \\
\hline In $(80 \mathrm{~kg})$ & $564^{\mathrm{b}}$ & $204^{\mathrm{b}}$ & $360^{\mathrm{c}}$ & $36^{\mathrm{ab}}$ & $101^{\mathrm{b}}$ & $40^{\mathrm{b}}$ & $61^{\mathrm{c}}$ & $40^{\mathrm{a}}$ \\
\hline \multicolumn{9}{|l|}{ Replicates } \\
\hline February-May & $589^{\mathrm{b}}$ & $204^{\mathrm{a}}$ & $385^{\mathrm{b}}$ & $35^{\mathrm{ab}}$ & $106^{\mathrm{c}}$ & $40^{\mathrm{a}}$ & $66^{\mathrm{b}}$ & $38^{\mathrm{a}}$ \\
\hline April-August & $580^{\mathrm{b}}$ & $217^{\mathrm{a}}$ & $363^{\mathrm{b}}$ & $37^{\mathrm{a}}$ & $104^{\mathrm{c}}$ & $44^{\mathrm{a}}$ & $61^{\mathrm{b}}$ & $42^{\mathrm{a}}$ \\
\hline July-November & $674^{\mathrm{a}}$ & $199^{\mathrm{a}}$ & $475^{\mathrm{a}}$ & $30^{\mathrm{b}}$ & $122^{\mathrm{a}}$ & $39^{\mathrm{a}}$ & $83^{\mathrm{a}}$ & $33^{\mathrm{a}}$ \\
\hline October-January & $677^{\mathrm{a}}$ & $228^{\mathrm{a}}$ & $448^{\mathrm{a}}$ & $34^{\mathrm{ab}}$ & $121^{\mathrm{ab}}$ & $46^{\mathrm{a}}$ & $75^{\mathrm{a}}$ & $38^{\mathrm{a}}$ \\
\hline
\end{tabular}

Values with the same superscript letter within each column are not significantly different $(P<0.05)$. NUE $=($ output/input $) \times 100$. 


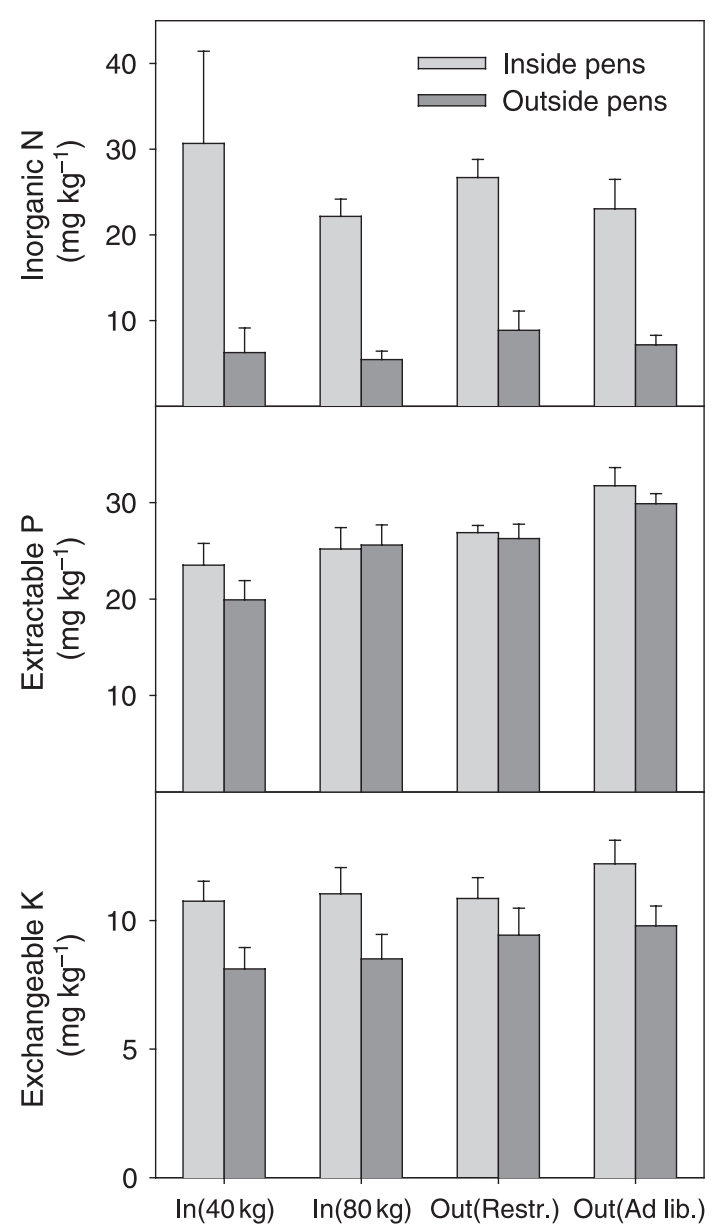

Figure 2 Mean concentrations of inorganic $\mathrm{N}$, extractable $\mathrm{P}$ and exchangeable $\mathrm{K}(0-40 \mathrm{~cm})$ in- and outside paddocks with different treatments of fattening pigs. For description of treatments, see Table 1.

\section{Deposition and distribution of nutrients}

The concentration of soil inorganic $\mathrm{N}$ was significantly higher in the paddocks than outside the paddocks (Figure 2a). On average the $\mathrm{N}$ concentration at $0-40 \mathrm{~cm}$ depth in- and outside the paddocks corresponded to 144 and $39 \mathrm{~kg} \mathrm{~N} \mathrm{ha}^{-1}$, respectively (soil bulk density c. $1.4 \mathrm{~kg} \mathrm{dm}^{-3}$ ). Even though the treatments did not differ in target $\mathrm{N}$ deposition, the timing of the manure excretion was different, varying from a large deposition for a short period (treatment 2) to smaller daily deposition spread over a much longer period (treatments 4 and 5). However, there were no significant differences between the treatments and similarly there was no effect of time of replication (data not shown). Despite the greater $\mathrm{N}$ concentrations inside paddocks, the measured inorganic $\mathrm{N}$ at $0-40 \mathrm{~cm}$ corresponded to only $18-32 \%$ of the $\mathrm{N}$ surplus of the $\mathrm{N}$ balance.

The concentration of extractable $\mathrm{P}$ was not significantly affected by pig grazing (Figure 2b) with similar concentra- tion in- and outside the paddocks. Similarly, there were no significant differences between individual treatments and replicates. The fact that a $\mathrm{P}$ surplus of $61-86 \mathrm{~kg} \mathrm{P} \mathrm{ha}^{-1}$ (Table 2) does not significantly raise the level of extractable $\mathrm{P}$ may be caused by $\mathrm{P}$ being in forms not extractable by the sodium bicarbonate (Neyroud \& Lischer, 2003), and furthermore, it may indicate that the soil has not reached $\mathrm{P}$ saturation.

Pigs on grassland significantly raised the concentration of exchangeable $\mathrm{K}$ (Figure 2c) but just as for inorganic $\mathrm{N}$ and extractable $\mathrm{P}$, there were no differences between individual treatments and replicates.

A prerequisite for efficient nutrient utilization is a homogeneous distribution of the manure to avoid hot spots. In this respect, the regular moving of huts, feeding and water troughs seemed successful as inorganic $\mathrm{N}$, extractable $\mathrm{P}$ and exchangeable $\mathrm{K}$ were distributed fairly evenly throughout the paddocks, although with some variation (Figures 3-5). For inorganic $\mathrm{N}$, it was possible to compare nutrient distribution with that of sows on grassland where no attempts had been made to obtain homogeneous distribution (Eriksen \& Kristensen, 2001). Based on a comparison of the weighted average within paddock variances for the two sets of trials, there was a significantly lower variance $(P<0.01)$ where measures were taken to increase the uniformity of deposition.

\section{Grass cover}

Grass cover at all points was determined using automatic measurements of spectral reflectance from which a relative vegetation index (RVI) was calculated. RVI was determined for bare soil and for $100 \%$ grass cover at each sampling date (Figure 6) because the value for full grass cover varied over the year. The grass cover at each point was then determined from interpolation between these. This is a new method for the estimation of grass cover, which may be criticized as the correlation between grass cover and RVI may not be linear. But we still consider this a great improvement on visual inspection as the data seems very reliable, more precise and the subjective and individual nature of visual determination is overcome.

Generally, the grass cover in the paddocks was more or less destroyed especially during autumn and winter. Although treatments had similar overall stocking density, the timing of grazing was different and small pigs may differ from grown pigs in the destruction caused. Despite these differences, grass cover was not related to the experimental treatments but only to the time of year (Figure 7). During spring and summer, some grass cover was present in isolated parts of the paddocks, whereas during autumn and winter the pigs kept grass cover below $10 \%$ at all times. There was no relationship between grass cover and soil inorganic $\mathrm{N}$. 

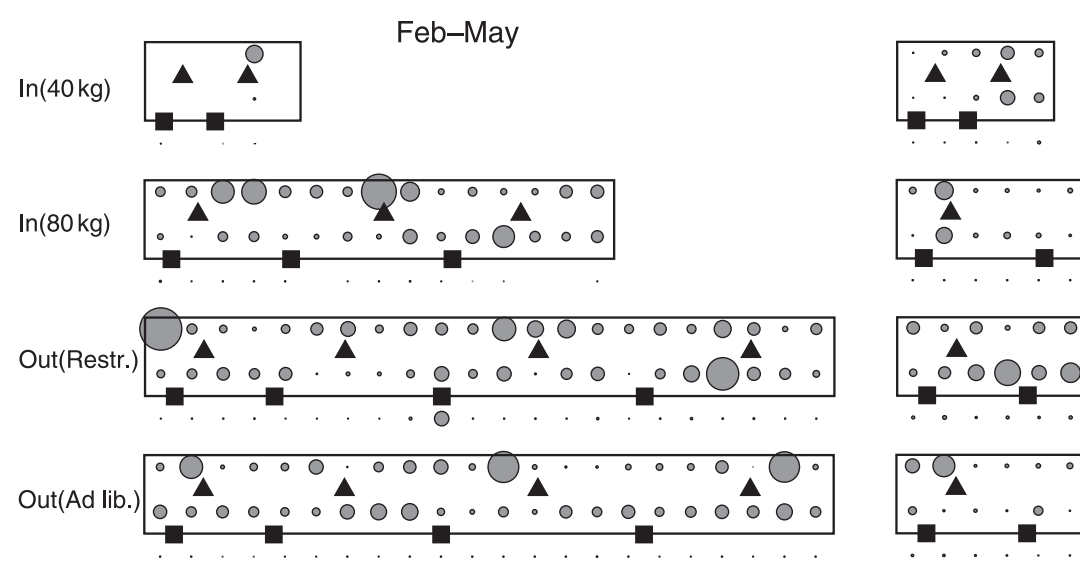

Apr-Aug
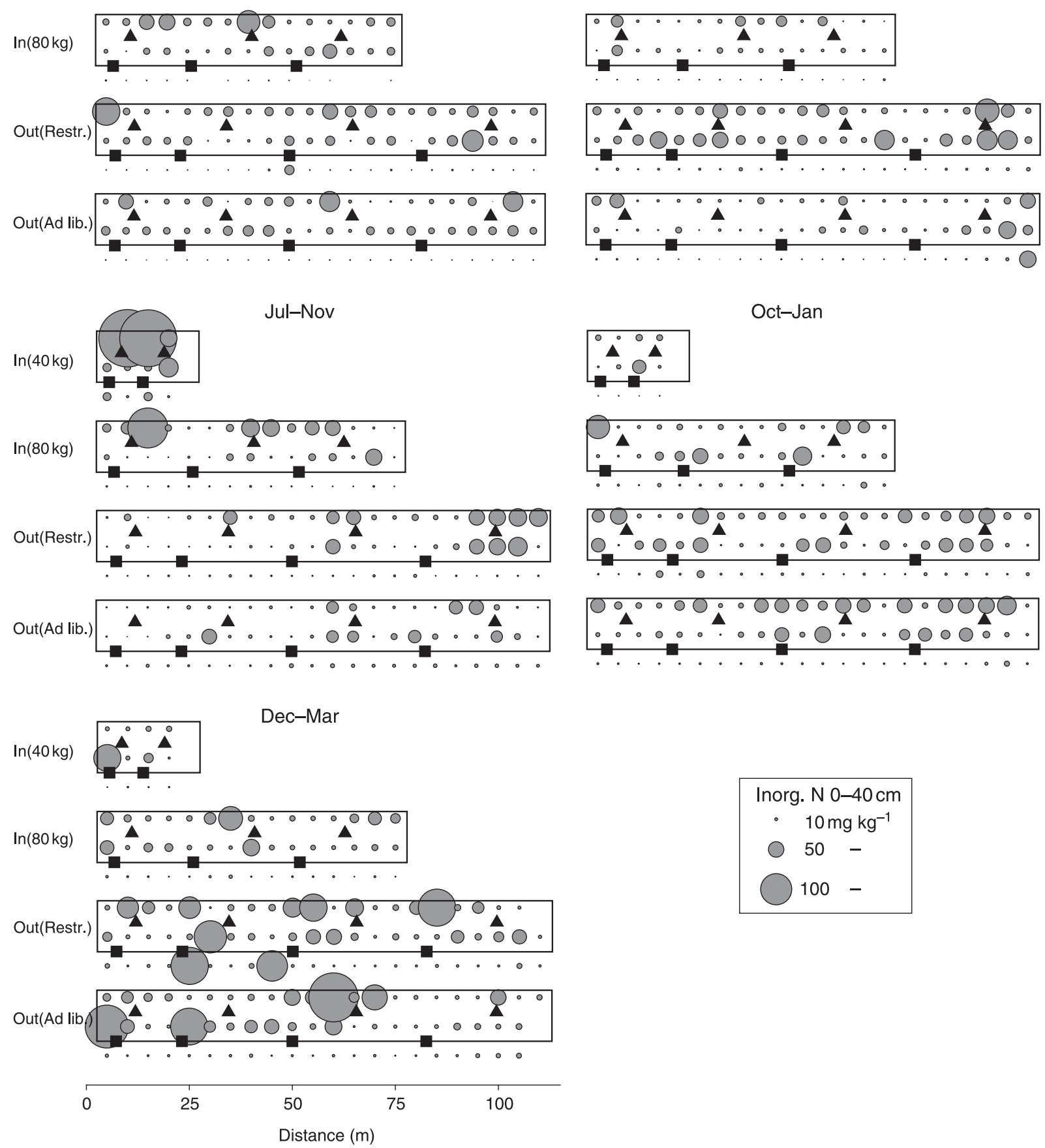

Figure 3 Bubble plot of $\mathrm{NO}_{3}-\mathrm{N}+\mathrm{NH}_{4}-\mathrm{N}(0-40 \mathrm{~cm})$ in- and outside the four paddocks in five replicates (time of year) of fattening pigs on pasture. Each paddock contained one hut $(\boldsymbol{\Lambda})$ and one feeding trough $(\boldsymbol{\square})$ that were moved every 4 weeks (from left to right). All positions during the experiment are shown. For description of treatments, see Table 1.

\section{Discussion}

The fate of $\mathrm{N}$ surpluses in the paddocks that originated from $\mathrm{N}$ excreted by the pigs would have been one or more of the following: uptake by plants, loss by nitrate leaching, ammonia volatilization or denitrification, and/or accumulation in soil organic matter. Thus, the large surpluses indicate large loss potential in these paddocks, because the majority of 
Feb-May

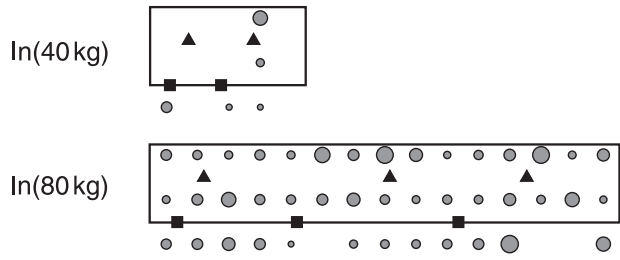

Out(Restr.) \begin{tabular}{|llllllllllllllllllllll}
0 & 0 & 0 & 0 & 0 & 0 & 0 & 0 & 0 & 0 & 0 & 0 & 0 & 0 & 0 & 0 & 0 & 0 & 0 & 0 & 0 & 0 \\
0 & 0 & 0 & 0 & 0 & 0 & 0 & 0 & 0 & 0 & 0 & 0 & 0 & 0 & 0 & 0 & 0 & 0 & 0 & 0 & 0 \\
\hline & 0 & 0 & 0 & 0 & 0 & 0 & 0 & 0 & 0 & 0 & 0 & 0 & 0 & 0 & 0 & 0 & 0 & 0 & 0 & 0 & 0
\end{tabular}

Out(Ad lib.) $\mid$\begin{tabular}{llllllllllllllllllllll|}
0 & 0 & 0 & 0 & 0 & 0 & 0 & 0 & 0 & 0 & 0 & 0 & 0 & 0 & 0 & 0 & 0 & 0 & 0 & 0 & 0 & 0 \\
0 & 0 & 0 & 0 & 0 & 0 & 0 & 0 & 0 & 0 & 0 & 0 & 0 & 0 & 0 & 0 & 0 & 0 & 0 & 0 & 0 \\
0 & 0 & 0 & 0 & 0 & 0 & 0 & 0 & 0 & 0 & 0 & 0 & 0 & 0 & 0 & 0 & 0 & 0 & 0 & 0 & 0 & 0
\end{tabular}

Jul-Nov

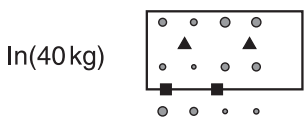

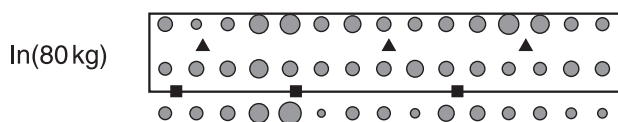

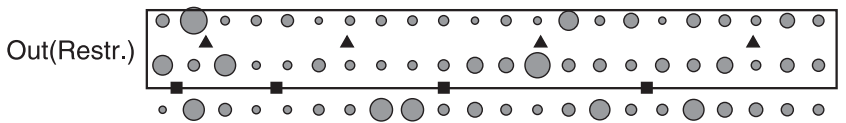

Out(Ad lib.) \begin{tabular}{|llllllllllllllllllllll|}
\hline 0 & 0 & 0 & 0 & 0 & 0 & 0 & 0 & 0 & 0 & 0 & 0 & 0 & 0 & 0 & 0 & 0 & 0 & 0 & 0 & 0 & 0 \\
0 & 0 & 0 & 0 & 0 & 0 & 0 & 0 & 0 & 0 & 0 & 0 & 0 & 0 & 0 & 0 & 0 & 0 & 0 & 0 & 0 & 0 \\
\hline & 0 & 0 & 0 & 0 & 0 & 0 & 0 & 0 & 0 & 0 & 0 & 0 & 0 & 0 & 0 & 0 & 0 & 0 & 0 & 0 & 0
\end{tabular}

Dec-Mar

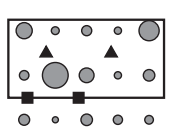

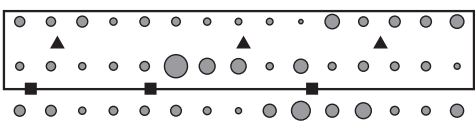
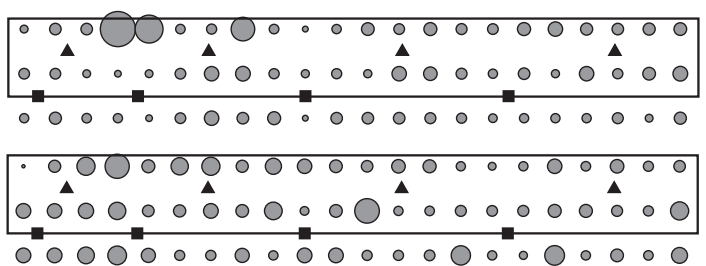

Oct-Jan
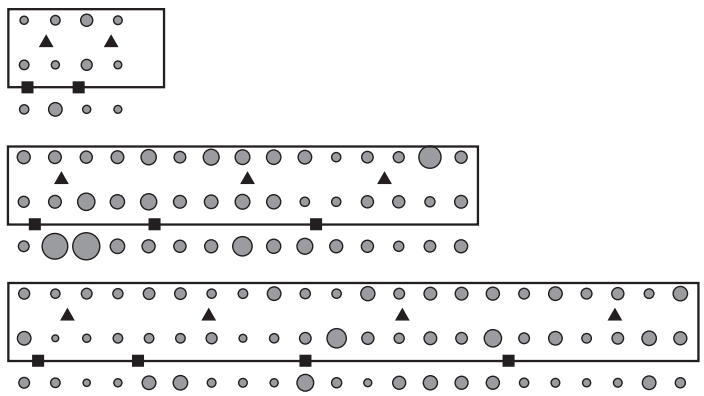

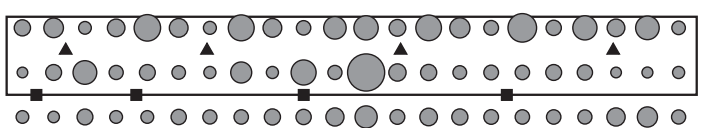

$\left.\ln (40 \mathrm{~kg}) \quad \begin{array}{cccc}0 & 0 & 0 & 0 \\ 0 & 0 & 0 & 0 \\ 0 & 0 & 0 & 0\end{array}\right]$

$\ln (80 \mathrm{~kg})\left[\begin{array}{lllllllllllllll}0 & 0 & 0 & 0 & 0 & 0 & 0 & 0 & 0 & 0 & 0 & 0 & 0 & 0 & 0 \\ 0 & 0 & 0 & 0 & 0 & 0 & 0 & 0 & 0 & 0 & 0 & 0 & 0 & 0 & 0 \\ 0 & 0 & 0 & 0 & 0 & 0 & 0 & 0 & 0 & 0 & 0 & 0 & 0 & 0 & 0\end{array}\right.$

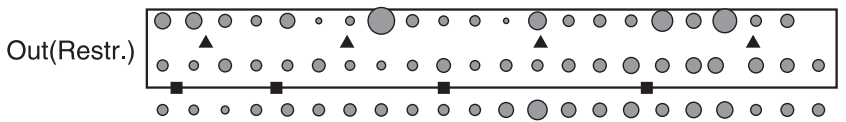

Out(Ad lib.) \begin{tabular}{|llllllllllllllllllllll|}
0 & 0 & 0 & 0 & 0 & 0 & 0 & 0 & 0 & 0 & 0 & 0 & 0 & 0 & 0 & 0 & 0 & 0 & 0 & 0 & 0 & 0 \\
0 & 0 & 0 & 0 & 0 & 0 & 0 & 0 & 0 & 0 & 0 & 0 & 0 & 0 & 0 & 0 & 0 & 0 & 0 & 0 \\
\hline & 0 & 0 & 0 & 0 & 0 & 0 & 0 & 0 & 0 & 0 & 0 & 0 & 0 & 0 & 0 & 0 & 0 & 0 & 0
\end{tabular}

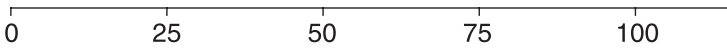

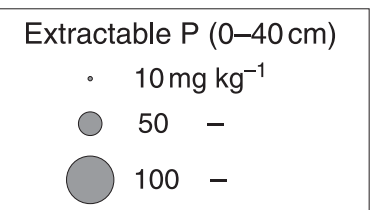

Distance (m)

Figure 4 Bubble plot of extractable soil $\mathrm{P}(0-40 \mathrm{~cm})$ in- and outside the four paddocks in five replicates (time of year) of fattening pigs on pasture. Each paddock contained one hut $(\mathbf{\Delta})$ and one feeding trough $(\square)$ that were moved every 4 weeks (from left to right). All positions during the experiment are shown. For description of treatments, see Table 1.

excreted $\mathrm{N}$ was inorganic and plant cover was negligible. This would have been the case even if the inorganic $\mathrm{N}$ in the soil was used efficiently by grass. The lack of plant cover may also have caused accumulation in soil organic matter to be small, although some of the unmineralized organic $\mathrm{N}$ in manure may have become available to the following crop. 

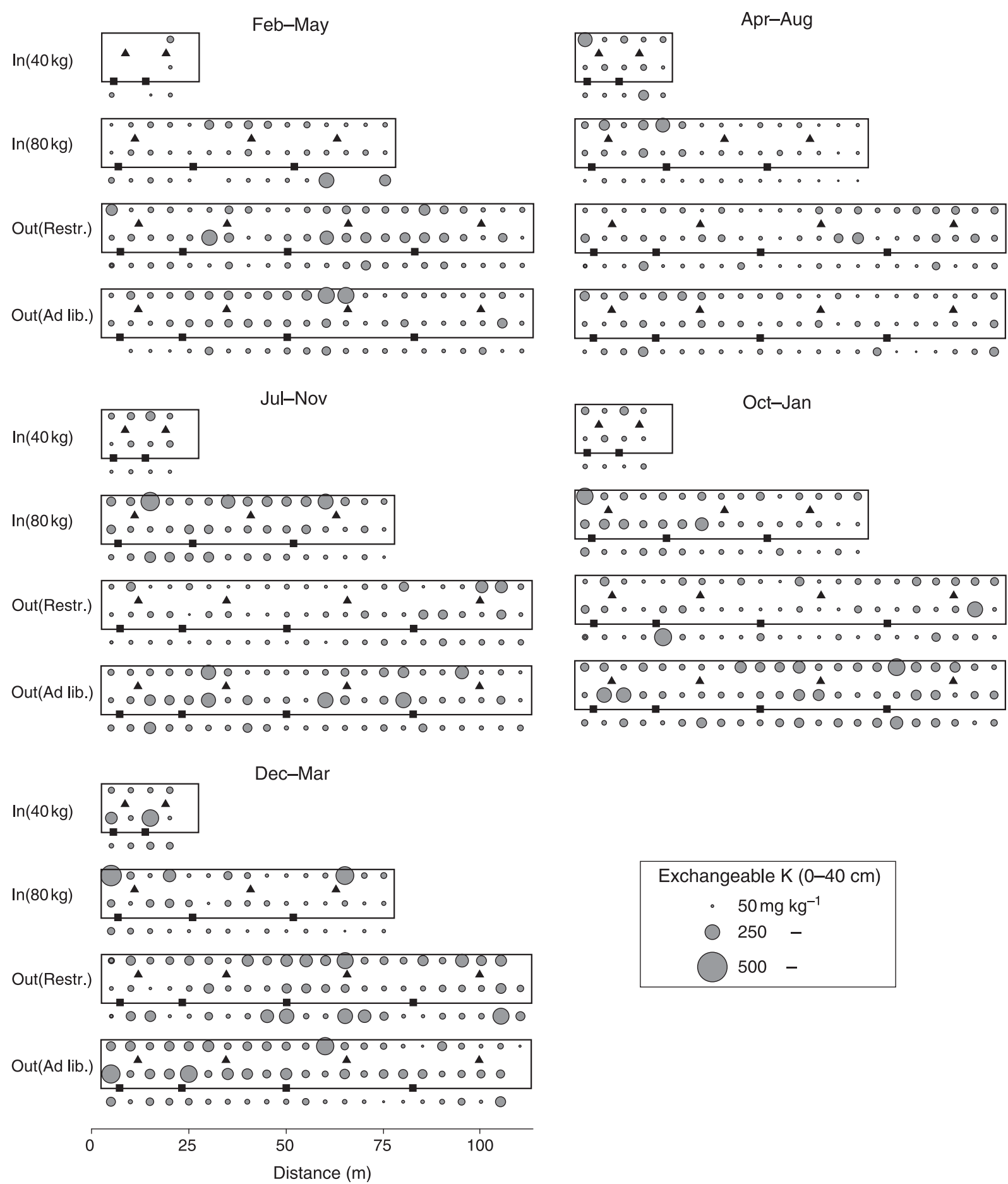

Figure 5 Bubble plot of exchangeable soil $\mathrm{K}(0-40 \mathrm{~cm})$ in- and outside the four paddocks in five replicates (time of year) of fattening pigs on pasture. Each paddock contained one hut $(\boldsymbol{\Lambda})$ and one feeding trough $(\boldsymbol{\square})$ that were moved every 4 weeks (from left to right). All positions during the experiment are shown. For description of treatments, see Table 1.

One measure to counteract such large nutrient loss potentials is a reduction in the dietary nutrient input. It is noteworthy that the higher $\mathrm{N}$ content of organic feeds than conventional feeds contribute to a greater risk of losses. The option is to reduce the dietary input through increasing the intake of grass by sows in the paddocks. Carlson et al. (1999) showed that herbage can constitute up to $20 \%$ of the daily dry matter intake of fattening pigs. However, the 


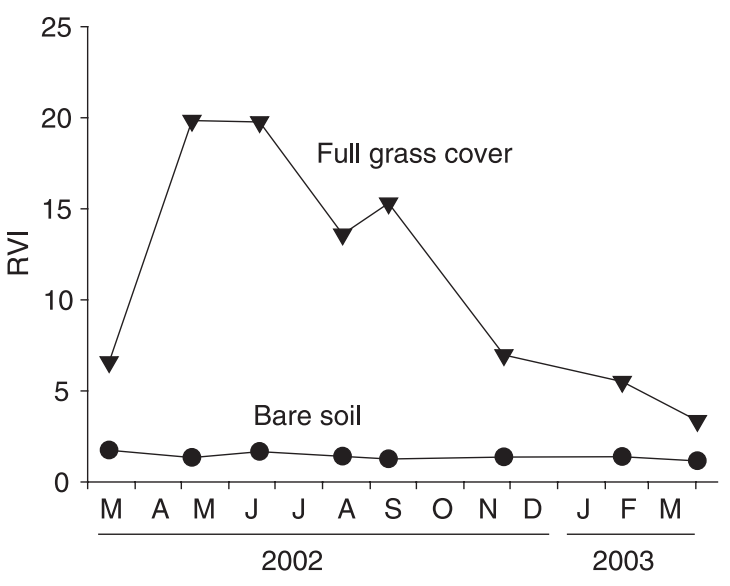

Figure 6 Measurements of relative vegetation index (RVI) by spectral reflectance from bare soil and full grass cover during the experimental period used for the determination of grass cover in paddocks with fattening pigs.

contribution to the energy supply of the pig when fed ad libitum only ranged from 2 to $8 \%$. This means that most feeds given to the fattening pigs need to be in the form of concentrates, which makes it difficult to substantially reduce the dietary input. It may be speculated that the nutrient $(\mathrm{N}$ and $\mathrm{P}$ ) content per energy unit of the feed could be reduced without impairing growth, because the demand for these nutrients would not be expected to be significantly increased by outdoor rearing. However, it seems likely that extra energy would be required for maintenance and locomotion. Another and probably more realistic option to reduce the nutrient surplus is by increasing the area to which the pigs have access, because reduced stocking rates will lead to reduced $\mathrm{N}$ leaching losses (Williams et al., 2005). For the pigs staying on pasture until slaughter, just to reduce the surplus to the $280 \mathrm{~kg} \mathrm{~N} \mathrm{ha}^{-1}$ that is currently the limit in Danish regulations, the size of the paddocks would have to be 39 and $81 \%$ larger for the restrictively and ad libitum fed pigs, respectively. This corresponds to a density of 65 restrictively fed and 50 ad libitum fed fattening pigs per hectare. In a similar system, Salomon et al. (2005) used 71 pigs per hectare.

The moving of huts, feeding and water troughs seemed reasonably effective in reducing hot spots caused by animal excretion. This is an important aspect of nutrient loss control in farm management. Several studies with outdoor pig production have shown that small areas of land chosen by the pigs for excretion receive excessive amounts of nutrients (e.g. Eriksen \& Kristensen, 2001; Watson et al., 2003), which represent a significant environmental risk. Eriksen et al. (2002) demonstrated the fate of $\mathrm{N}$ in this situation and Watson et al. (2003) showed that the soil became saturated with $\mathrm{P}$ in such preferred areas. The capacity of our soil to adsorb $\mathrm{P}$ was not investigated, but may be subject to further study. It is clear that any evaluation of nutrient loss potential based on nutrient balances should be supplemented with soil

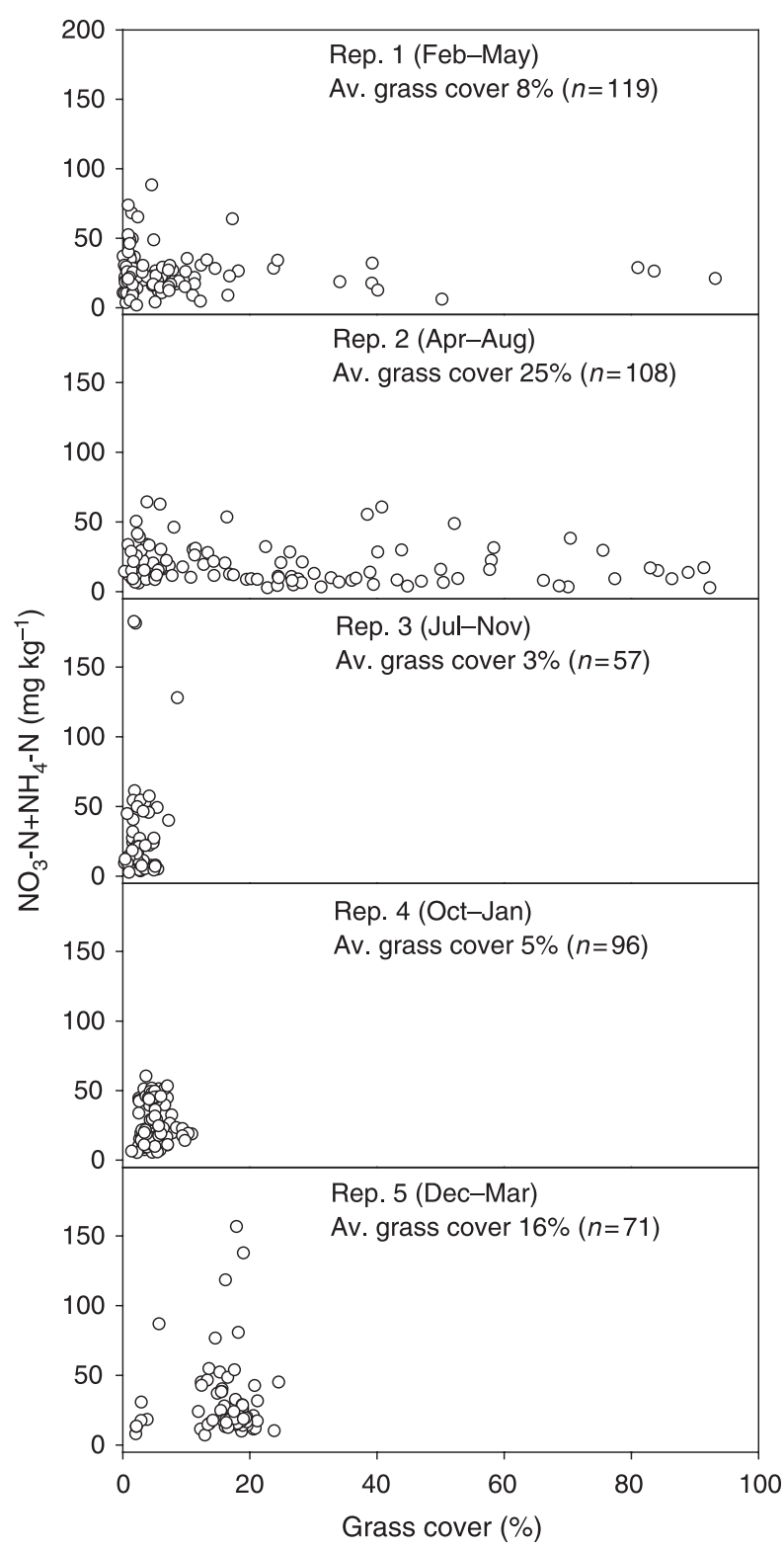

Figure 7 Relationship between grass cover (RVI) and $\mathrm{NO}_{3}-\mathrm{N}+$ $\mathrm{NH}_{4}-\mathrm{N}$ content in localized parts of paddocks in five replicates (time of year) of fattening pigs on pasture.

analyses to validate if spatial variability has been profoundly influenced by outdoor pig production.

In the experiment, it proved impossible to maintain a grass cover in paddocks with fattening pigs at the current stocking rate. In paddocks with sows, ringing is often successfully used to prevent rooting and damage to the sward (Hermansen et al., 2004). However, this is not possible and also probably not desirable for fattening pigs, as the ringing prevents a basic behaviour by causing pain to the animal. It has been demonstrated that rooting is the preferred explorative behaviour of pigs (Studnitz et al., 2003) and it is considered a behavioural need (Horrel et al., 2001), which must be taken into 
consideration, especially in organic production systems. However, a well-maintained grass sward decreases the risk of nitrate leaching (Watson et al., 2005). Thus, a difficult challenge is to develop production systems that provide the behavioural needs of the pigs while maintaining a reasonable crop cover prior to and during periods when water percolating through the soil leaches nitrate out of the soil profile.

From an environmental point of view, seasonal production (February-August) of fattening pigs on pasture followed by a nutrient-demanding catch crop or main crop seems a viable option. Another possible strategy is a reduction in stocking rate during autumn and winter, a strategy that calls for careful management to avoid an uneven distribution of nutrients. Alternatively, advantage could be taken of the rooting activities of the pigs. Andresen et al. (2001) showed that pigs could be used for mechanical tillage. However, this requires a high stocking rate for a short period of time, which is labour demanding because of the extra fencing needed.

\section{Conclusions}

Organic production of pigs stipulates summer grazing, although the present use of indoor facilities is accepted as long as there is access to an outdoor area. However, keeping pigs on pasture carries a high risk of environmental damage because of $\mathrm{N}$ loss. Certainly, the nutrient loss potential in our experiment was great and would inevitably have led to large actual losses. This highlights the importance of reducing stocking density and the level of dietary N. The data also showed that uniform distribution may be obtained if huts, feeding and water troughs are moved regularly.

Considering the problems of maintaining grass cover, high levels of nutrient deposition may only be acceptable if it is followed immediately by a nutrient-demanding catch crop or main crop. This is possible if fattening pigs are on pasture only from February to August. Thus, the most environmentally acceptable way of keeping fattening pigs on pasture seems to involve a combination of reduced dietary $\mathrm{N}$ intake, reduced stocking rate and restricted seasonal production.

\section{Acknowledgements}

The technical assistance of Jens Bonderup Kjeldsen and the staff at Rugballegaard Experimental Station is gratefully acknowledged.

\section{References}

Andresen, N., Ciszuk, P. \& Ohlander, L. 2001. Pigs on grassland: animal growth rate, tillage work and effects in the following winter wheat crop. Biological Agriculture and Horticulture, 18, 327343.

Carlson, D., Lærke, H.N., Poulsen, H.D. \& Jørgensen, H. 1999. Roughages for growing pigs, with emphasis on chemical composi- tion, ingestion and faecal digestibility. Acta Agriculturae Scandinavica. Section A, Animal Science, 49, 129-136.

Eriksen, J. 2001. Implications of grazing by sows for nitrate leaching from grassland and the succeeding cereal crop. Grass and Forage Science, 56, 317-322.

Eriksen, J. \& Kristensen, K. 2001. Nutrient excretion by outdoor pigs: a case study of distribution, utilisation and potential for environmental impact. Soil Use and Management, 17, 21-29.

Eriksen, J., Petersen, S.O. \& Sommer, S.G. 2002. The fate of nitrogen in outdoor pig production. Agronomie, 22, 863-867.

European Commission. 2000. Nitrates Directive (91/676/EEC). Status and trends of aquatic environment and agricultural practice - development guide for member states' reports. Office for Official Publications of the European Communities, Luxembourg, pp. 1-42.

Fernandez, J.A., Poulsen, H.D., Boisen, S. \& Rom, H.B. 1999. Nitrogen consumption, utilization and losses in pig production: Denmark. Livestock Production Science, 58, 225-242.

Hermansen, J.E., Strudsholm, K. \& Horsted, K. 2004. Integration of organic animal production into land use with special reference to swine and poultry. Livestock Production Science, 90, 11-26.

Horrel, I., A'Ness, P., Edwards, S.A. \& Eddison, J. 2001. The use of nose-ringing in pigs: consequences for rooting, other functional activities, and welfare. Animal Welfare, 10, 3-22.

Ministry of Environment. 2002. Executive order on commercial livestock farming, manure, silage etc. (in Danish). BEK. no. 604 of 15/ 07/2002, chapters 1-14.

Møller, J., Thøgersen, R., Kjeldsen, A., Weisbjerg, M.R., Søegaard, K., Hvelplund, T. \& Børsting, C.F. 2000. Feedstuff tables. (in Danish) Landsudvalget for Kvæg Report no. 91.

Neyroud, J.-A. \& Lischer, P. 2003. Do different methods used to estimate soil phosphorus availability across Europe give comparable results? Journal of Plant Nutrition and Soil Science, 166, 422-431.

Öborn, I., Edwards, A.C., Witter, E., Oenema, O., Ivarsson, K., Withers, P.J.A., Nilsson, S.I. \& Richert Stinzing, A. 2003. Element balances as a tool for sustainable nutrient management: a critical appraisal of their merits and limitations within an agronomic and environmental context. European Journal of Agronomy, 20, 211225.

Oksbjerg, N., Strudsholm, K., Lindahl, G. \& Hermansen, J.E. 2005. Meat quality of fully or partly outdoor reared pigs in organic production. Acta Agiculturae Scandinavica, Section A, 55, 106-112.

Olsen, S.R., Cole, C.V., Watanabe, F.S. \& Dean, L.A. 1954. Estimation of available phosphorus in soils by extraction with bicarbonate. U.S. Department of Agriculture, Circular, 939, 1-29.

Pedersen, C.A. 2000. Overview of national experiments (in Danish). Landsudvalget for Planteavl, Skejby, Denmark.

Petersen, S.O., Kristensen, K. \& Eriksen, J. 2001. Denitrification losses from outdoor piglet production: spatial and temporal variability. Journal of Environmental Quality, 30, 1051-1058.

Poulsen, H.D. \& Kristensen, V.F. 1997. Standard values for nutrient content of animal manure (in Danish). Report no. 736. Danish Institute of Agricultural Sciences, Tjele, Denmark.

Ryden, J.C., Ball, P.R. \& Garwood, E.A. 1984. Nitrate leaching from grassland. Nature, 311, 50-53.

Salomon, E., Benfalk, C., Geng, Q., Lindahl, C., Lindgren, K. \& Torén, A. 2005. Outdoor pig systems in organic agriculture - animal environment, plant nutrient management and working environment. NJF Report 1, 203-206. Nordic Association of Agricultural 
Scientists, Royal Swedish Academy of Agriculture and Forestry, Stockholm, Sweden.

SAS Institute Inc. 1999. SAS/STAT® User's Guide, Version 8. SAS Institute Inc., Cary, NC.

Sather, A.P., Jones, S.D.M., Schaefer, A.L., Colyn, J. \& Robertson, W.M. 1997. Feedlot performance, carcass composition and meat quality of free-range reared pigs. Canadian Journal of Animal Science, 77, 225-232.

Schjønning, P., Munkholm, L.J., Rasmussen, K.J. \& Nielsen, P.S. 2002. Soil tillage in organic farming - ploughing depth and noninversion deep tillage (in Danish). Report no 82. Danish Institute of Agricultural Sciences, Tjele, Denmark.

Schulze, E.D., Devries, W. \& Hauhs, M. 1989. Critical loads for nitrogen deposition on forest ecosystems. Water, Air and Soil Pollution, 48, 451-456.

Searle, S.R., Casella, G. \& McCulloch, C.E. 1992. Variance Components. John Wiley \& Sons, Inc., New York.

Sommer, S.G., Søgaard, H.T., Møller, H.B. \& Morsing, S. 2001. Ammonia volatilization from pigs on grassland. Atmospheric Environment, 35, 2023-2032.

Stern, S. \& Andresen, N. 2003. Performance, site preferences, foraging and excretory behaviour in relation to feed allowance of growing pigs on pasture. Livestock Production Science, 79, 257-265.

Strudsholm, K. \& Hermansen, J.E. 2005. Performance and carcass quality of fully or partly outdoor reared pigs in organic production. Livestock Production Science, 96, 261-268.
Studnitz, M., Jensen, K.H., Jørgensen, E. \& Jensen, K.K. 2003. The effect of nose ringing on explorative behaviour in gilts. Animal Welfare, 12, 109-118.

Thomas, G.W. 1982. Exchangeable cations. In: Methods of soil analysis. Part 2 (eds A.L. Page, R.H. Miller \& D.R. Keeney), pp. 159-165. ASA and SSSA, Madison, WI.

Wang, W.C., Yung, Y.L., Lacis, A.A., Mo, T. \& Hansen, J.E. 1976. Greenhouse effects due to man-made perturbations of trace gases. Science, 194, 685-690.

Watson, C.A., Atkins, T., Bento, S., Edwards, A.C. \& Edwards, S.A. 2003. Appropriateness of nutrient budgets for environmental risk assessment: a case study of outdoor pig production. European Journal of Agronomy, 20, 117-126.

Watson, C.A., Öborn, I., Eriksen, J. \& Edwards, A.C. 2005. Perspectives on nutrient management in mixed farming systems. Soil Use and Management, 21, 132-140.

Williams, J.R., Chambers, B.J., Hartley, A.R., Ellis, S. \& Guise, H.J. 2000. Nitrogen losses from outdoor pig farming systems. Soil Use and Management, 16, 237-243.

Williams, J.R., Chambers, B.J., Hartley, A.R. \& Chalmers, A.G. 2005. Nitrate leaching and residual soil nitrogen supply following outdoor pig farming. Soil Use and Management, 21, 245252.

Zihlmann, U., Weisskopf, P., Menzi, H. \& Ingold, U. 1997. Bodenbelastung durch freilandschweine. Agrarforschung, 4, 459462. 